\title{
Preventive Interfaith Marriage Conflicts Through Assistance for Hindu Families Based on Swadharma Grahasta Dormitory in Ngis Hamlet, Buwun Sejati Village, Narmada District, West Lombok Regency
}

\section{Ketut Putu Suardana1, Sayu Kadek Jelantik ${ }^{2}$, Rieka Yulita Widaswara ${ }^{3}$, Ni Nyoman Harnika ${ }^{4}$}

Institut Agama Hindu Negeri Gde Pudja Mataram ${ }^{1,2,3,4}$

Email: ikp31suardana@gmail.com¹ ${ }^{1}$, sayujelantik@gmail.com² ${ }^{2}$ riekawidaswara@gmail.com³ ninyomanharnika@gmail.com ${ }^{4}$

\begin{tabular}{ll}
\hline Article History: & Abstract: The community service program \\
Received: July $10^{\text {th }} 2020$ & carried out by the Hindu Religious Information \\
Revised: Aug $2^{\text {nd }} 2021$ & Study Program aims to strengthen religious \\
Accepted: Nov $31^{\text {st }} 2021$ & character, increase sradha and devotion to the \\
& younger generation of Hindus through family \\
& communication based on swadharma grahasta \\
& asrama to improve the method used, namely \\
& service learning which consists of the preparation \\
& stage, service stage, and also the reflection stage. \\
& The results of this service are that there is a \\
& strengthening of religious character in the form of \\
& increasing devotional service for the younger \\
& generation of Hindus through family \\
& communication assistance, the formation of the \\
Widya Gitanjali Pasraman as a non-formal \\
Keywords: Prevention Of & educational institution as a forum for learning \\
Family Communication, & Hinduism for the younger generation of Hindu \\
Grahasta Asrama. & Dusun Ngis in an effort to strengthen character, \\
& increase sradha and bhakti in an integrated \\
& manner, sustainable.
\end{tabular}

\section{Introduction}

Universities in Indonesia in principle have the same responsibility in devoting their dharma of service to the homeland and nation. Referring to the Law of the Republic of Indonesia Number 12 of 2012 concerning Higher Education, 12 of the President of the Republic of Indonesia ${ }^{1}$, universities are obliged to implement the tri dharma. The Tridharma of Higher Education is the basis for realizing the essential vision and mission. In fact, universities have the following functions. First, as a place for 
the transformation of knowledge. Second, as a developer of civilization through research. Third, as an applicator of knowledge in social life through community service activities.

Gde Pudja Mataram State Hindu High School (STAHN) is one of the higher education institutions consisting of an intellectual community tasked with developing the tri dharma of higher education which refers to the vision and mission of the STAHN Gde Pudja Mataram institution. Tridharma of higher education in this case teaching, research, and community service. The function of community service as the third dharma for a university, the practice of science and technology and religion for the benefit of humans, and the progress of the wider community so that service is a must for a university. This is inseparable from the Vision and Mission of STAHN Gde Pudja Mataram to participate in improving the professionalism of the institution, the development, and the progress of human resources. Referring to the Regulation of the Minister of Religion of the Republic of Indonesia Number 19 of 2 concerning the Statute of the Gde Pudja Mataram State Hindu High School, STAHN's vision is "As a superior and competitive center for Hindu studies". The missions of STAHN are: (1) to carry out education based on Hindu religion and culture, science and technology, and the arts; (2) Develop a scientific mindset in Hindu research and study, science and technology, and the arts; (3) Carrying out community service as a vehicle for the application of scientific fields and fostering sensitivity to the environment.

STAHN Gde Pudja Mataram has the same duties and responsibilities as other public universities in creating quality human resources in accordance with the demands of national education goals as stated in Law Number 20 of ${ }^{3}$ concerning the National Education System. To demonstrate the achievement of these targets, one of the movements that need to be carried out and continue to be developed is to upload academic people in running the tri dharma program of higher education. STAHN Gde Pudja Mataram needs to participate in contributing in preparing to improve the quality of human resources who have noble character and high independence for this purpose to carry out community service. The location of the service was chosen in Ngis Hamlet, Buwun Sejati Village, Narmada District, West Lombok Regency, West Nusa Tenggara Province. Based on data from the Central Statistics Agency (BPS) of West Lombok Regency in ${ }^{4}$, Buwun Sejati Village is the second largest village of 21 (twenty-one) villages in Narmada District which borders the forest in the north. Unfortunately, the village only has 2 (two) elementary school educational institutions that accommodate Hindus from the village because other educational institutions are private and are religious education institutions for people of other religions. In addition, the issue of interfaith marriage also often occurs in this village, this was also conveyed in the

\footnotetext{
22016

32003

42020
} 
discussion of the activities of the Religious Harmony Forum (FKUB), the Interfaith Youth Forum (FPLA), and the National Assimilation Forum (FPK) Head of Sub-Division of Administration Suparlan as the secretary of FKUB North Lombok Regency said that there are 2 (two) problems that need to be resolved and joint deliberation in North Lombok Regency which until now there has been no clear regulation including the problem of establishing houses of worship and interfaith marriages. These two contents, which are the main issues, need to be resolved and regulations made, and a verification team from FKUB needs to be made regarding the establishment of houses of worship, according to an excerpt from the speech of the FKUB Secretariat 5 .

In line with this, Saturday, March 4, 2017, at the Jagaraga Indah Village Office Hall, there was a mediation related to interfaith marriage between a woman named Hulfah Umraini, 26, a Muslim, at Ampenan, Mataram City. Meanwhile, from the male party, Ketut Putu Astawa, 28 years old, Hindu, who is from Karang Lamper, Jagaraga Indah Village, the interfaith couple was mediated at the Jagaraga Indah Village Office because the woman's family objected to interfaith marriages. Initially Sapri, the woman's parents tried to meet directly with the village head of Jagaraga Indah to discuss the mediation meeting so that it could be held immediately without delaying time. The mediation meeting was attended by the Village Head, Bhabinkamtibmas from the Police, Bhabinsa from the TNI? The Head of the Women's Environment, Toga, Tomas Jagaraga Indah Village and the families of both women and men were also present at the mediation meeting. "I was a family apologize profusely because we have not been able to accept this marriage," Sapri said Ulfa's parents. Meanwhile, the men seemed to understand this and were willing to accept if the two people of different religions were separated. After hearing from both parties, the Village Head of Jagaraga Indah and the participants of the mediation meeting agreed to settle it peacefully by making a statement. "If in the future it is known that women have come looking for men, the marriage will still be carried out in accordance with Hindu religious customs." said the Head of Jagara Indah Village. Then the statement letter was signed by both parties and witnesses and then forwarded to various relevant agencies such as the District, Polsek, and Danramil Kediri 6.

Lombok Island is located to the east of the island of Bali and to the west of the island of Sumbawa. In the west, there is the Lombok strait and in the east, there is the Alas strait. To the north of Lombok is the Java Sea and to the south is the Indonesian Ocean. Lombok Island is divided into three district governments and one city government, namely East Lombok Regency, Central Lombok Regency, West Lombok Regency, and Mataram City ${ }^{7}$. The Sasak are the indigenous people and the majority ethnic group in Lombok. Their number reaches more than $90 \%$ of the total population

\footnotetext{
${ }^{5}$ Kementerian Agama NTB, "Suparlan : " PR FKUB, Masalah Nikah Beda Agama Dan Rumah Ibadah.” 6 "Mediasi Kawin Selarian Beda Agama," Diskominfo Dan Statistik Kabubaten Lombok Barat.

${ }^{7}$ Erni Budiwanti, Islam Sasak; Wetu Telu Versus Waktu Lima (LKIS PELANGI AKSARA, 2000).
} 
of Lombok. Other ethnic groups such as Balinese, Sumbawa, Bima, Javanese, Arab and Chinese are immigrants. The Balinese are the largest immigrant ethnic group in Lombok, accounting for almost 3\% of the total population of Lombok ${ }^{8}$. Basically, in addition to the Sasak tribe which is dominated by Muslims in Lombok, there are also Balinese Hindus who live side by side, but this often results in interfaith marriages among the younger generation.

Based on the results of an initial survey conducted by the service team in an effort to explore the issues that exist in the Dusun Ngis community, namely the need for a Hindu religious learning forum for the Hindu generation in the area, both for children and teenagers. In addition, the Ngis hamlet community requires a discussion of family communication assistance regarding religious understanding to prevent interfaith marriages in the younger generation of Hindu Dusun Ngis. Interfaith marriage events which also have the potential to cause socio-cultural friction, low interest in continuing education at the tertiary level due to remote access are also a problem, and lack of awareness to communicate effectively between family members about religious teachings that must be understood and imitated because of their activities. Farming, which almost spends all day being separated from family due to gardens or fields and rice fields, is an indicator of the importance of implementing community service in this place.

The aim is none other than sharing thoughts with the community in an effort to optimize and build effective communication in the family about understanding Hindu religious teachings, strengthening sraddha bhakti so as to suppress conflicts and interfaith marriages which are the main issues that are needed in the service activities carried out. Referring to the explanation above, the implementation of Community Service in Ngis Hamlet, Buwun Sejati Village, Narmada District, is considered very important in order to improve effective communication between Hindu families in order to increase community service regarding understanding religious teachings. Therefore, a community service activity was carried out entitled "Preventive Religious Conflicts of Interfaith Marriages Through Assistance for Hindu Families Based on Swadharma Grahasta Dormitory in Ngis Hamlet, Buwun Sejati Village, Narmada District, West Lombok Regency".

\section{Method}

The implementation of community service is carried out using the servicelearning method. The service-learning method is a learning method that connects the material and theory obtained in the classroom to apply it into real action in the form of community service. On the other hand, ${ }^{9}$ ) said that service-learning combines academic

8 Erni Budiwanti, “Adat, Islam, and Dakwah Movement in Bayan, North Lombok," Heritage of Nusantara: International Journal of Religious Literature and Heritage (2016).

${ }^{9}$ Setyowati and Permata $(2018$ 
goals in the form of achieving knowledge, experience, and reflection in crossdisciplinary courses with problem-solving skills in the community. The stages of implementing this service can be seen in the following picture:

\section{DIAGRAM TAHAPAN PENGABDIAN KEPADA MASYARAKAT}

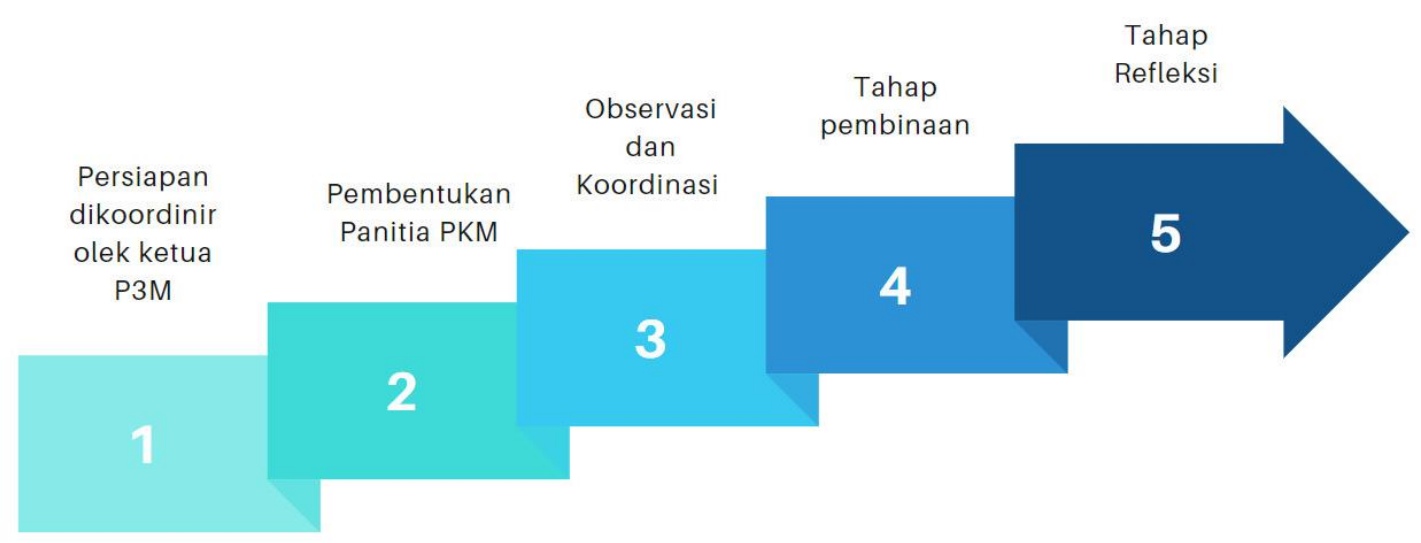

Picture 01. Stages of Community Service

The service preparation stage is as follows, this community service activity program is coordinated by the head of P3M, then followed up through the formation of an activity operational committee and coordinating with the Head of Ngis Hamlet, Buwun Sejati Village, Narmada District, West Lombok Regency to explore problems that exist in the location as well as discuss program activities in coaching related to issues encountered in the field. In the preparation stage, the community service team got an issue regarding the problems experienced by several young Hindu generations in the village experiencing interfaith marriages, so it was necessary to contribute ideas from the community service team regarding strengthening sraddha and filial piety, mentoring through communication to the younger generation to build enthusiasm in taking education both formally and participating in pasraman activities as a non-formal educational institution.

The service stage of activities is carried out by fostering religious education by the service team by means of dharma discourse, dharma tula, ceremonial development, and mutual cooperation, through assistance to adults, the younger generation, and also children. In adult mentoring, namely parents, dharma tula or question and answer lectures about interfaith marriages and efforts to form pasraman as non-formal education is carried out in that location as a learning area for the younger generation and children in Ngis Hamlet. Assistance to adult women regarding the formation of ceremonies for prayer facilities. For the younger generation, journalistic literacy assistance and dance training are provided. Coaching at the age of children is about fostering daily prayers, singing religious songs. All program activities are carried out in the morning until the evening. Each program implementation is carried out for a 
minimum of 8 hours of coaching according to the agreement of the participants. All coaching activities are facilitated by the service team, for example, consumption and learning aids needed, while the location is provided by participants who are residents of Ngis Hamlet, Buwun Sejati Village, Narmada District. In essence, the development of dharma gita, dharma discourse, dharma tula, upakara development, and various religious understandings is synergized with the main issue, namely strengthening sraddha and devotion.

The reflection stage in this activity is the formation of pasraman as an effort of non-formal educational institutions for the younger generation in the hamlet. The establishment of the Widya Gitanjali Pasraman is evidence of the efforts of Hindus in Ngis Hamlet, Buwun Sejati Village to continue to strengthen religious character by continuing to deepen their religious knowledge, especially the younger generation.

\section{Result}

\section{a. Location}

The implementation of community service activities was carried out in Ngis Hamlet, Buwun Sejati Village, Narmada District, West Lombok Regency, West Nusa Tenggara Province. The location determination was based on a request from the Chairperson of the Parisada Hindu Dharma Indonesia (PHDI) of West Lombok Regency to the Chairperson of STAHN Gde Pudja Mataram, who is currently promoted to the State Hindu Institute (IAHN) Gde Pudja Mataram. The location of the service is precisely in the administrative area of Buwun Sejati Village, it can be seen from picture 02 below:

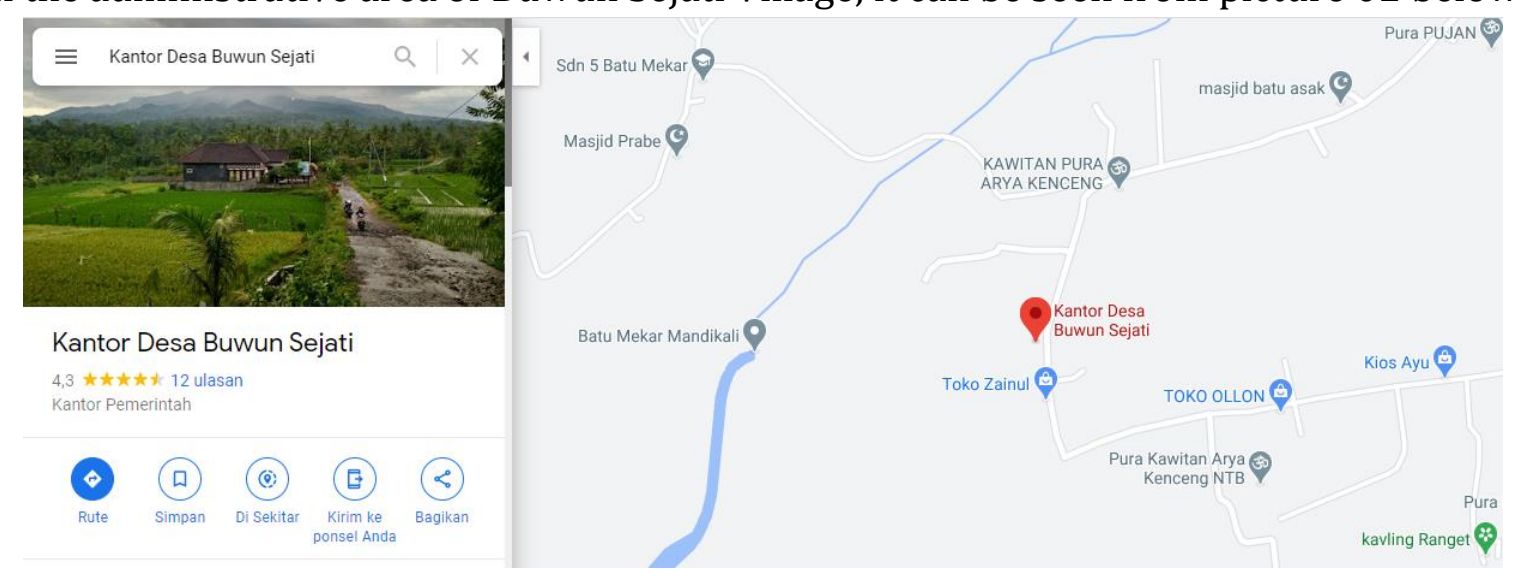

Picture 02. Map of Village Buwun Sejati 10

The preparatory stage carried out in the service was exploring the issue of the need for a Hindu religious learning forum for the Hindu generation in the area, both for children and teenagers. In addition, the Ngis hamlet community requires a discussion of family communication assistance regarding religious understanding to prevent interfaith marriages in the younger generation of Ngis Hindu Dusun, the lack of awareness to communicate effectively between family members about religious teachings that must be understood and imitated because farming activities that almost

10 Google Maps, “Desa Buwun Sejati.” 
spend The time of day being separated from family due to the garden or fields and rice fields is an indicator of the importance of implementing community service in this place.

The stage of implementing community service at the location was carried out well. The public's interest in learning is very high because this activity is an activity that the local community has received for the first time. Most of the community and parents seemed enthusiastic about participating in the activities. The service stage of activities is carried out by fostering religious education by the service team by means of dharma discourse, dharma tula, ceremonial development, and mutual cooperation, through assistance to adults, the younger generation, and also children. In adult mentoring, namely parents, dharma tula, or question and answer lectures about interfaith marriages and efforts to form pasraman as non-formal education is carried out in that location as a learning area for the younger generation and children in Ngis Hamlet. Assistance to adult women regarding the formation of ceremonies for prayer facilities. For the younger generation, journalistic literacy assistance and dance training are provided. Coaching at the age of children is about fostering daily prayers, singing religious songs.

Several significant results related to optimizing family communication based on Swadharma Grahastha Dormitory are useful for the community after the implementation of this service which consists of various target segments. Among them are the adult segment, the youth segment, and the children segment. The people who follow the guidance in the adult segment consist of Hindus who are over 18 years old or are married. In the youth segment are young people who are Hindus aged between 12 (Twelve) years to 18 (Eighteen) years. The children segment consists of children aged 12 (twelve) years and under. Based on the segmentation of the participants, after the implementation of community service, the results are presented as follows.

\section{b. Implementation of Tattwa Teachings And Customary Law of Interfaith Marriages}

The preparation stage based on the exploration of issues carried out by the service team requires a discussion or brainstorming between the community service team regarding the teachings of tattwa and the customary law of interfaith marriage.

The stage of mentoring services for the adult segment, namely parents, places more emphasis on discussions about tattwa teachings and customary law of interfaith marriages, as well as swadharma or parental obligations to children in order to provide understanding to children through intensive family communication. Hindus in the adult segment in Ngis Hamlet are able to implement the teachings of tattwa and the customary law of interfaith marriages. This is implemented through intensive communication between families. Parents provide guidance to their children regarding the impact of interfaith marriages. Parents nurture their children to maintain tolerance and harmony between religions. They have realized the negative and positive impacts of 
interfaith marriages through discussions that are packaged in the Dharma discourse and Dharma tula methods. Dharma discourse is a lecture method while Dharma Tula is a discussion method. The implementation of these activities can be seen in pictures 03 and 04 below:

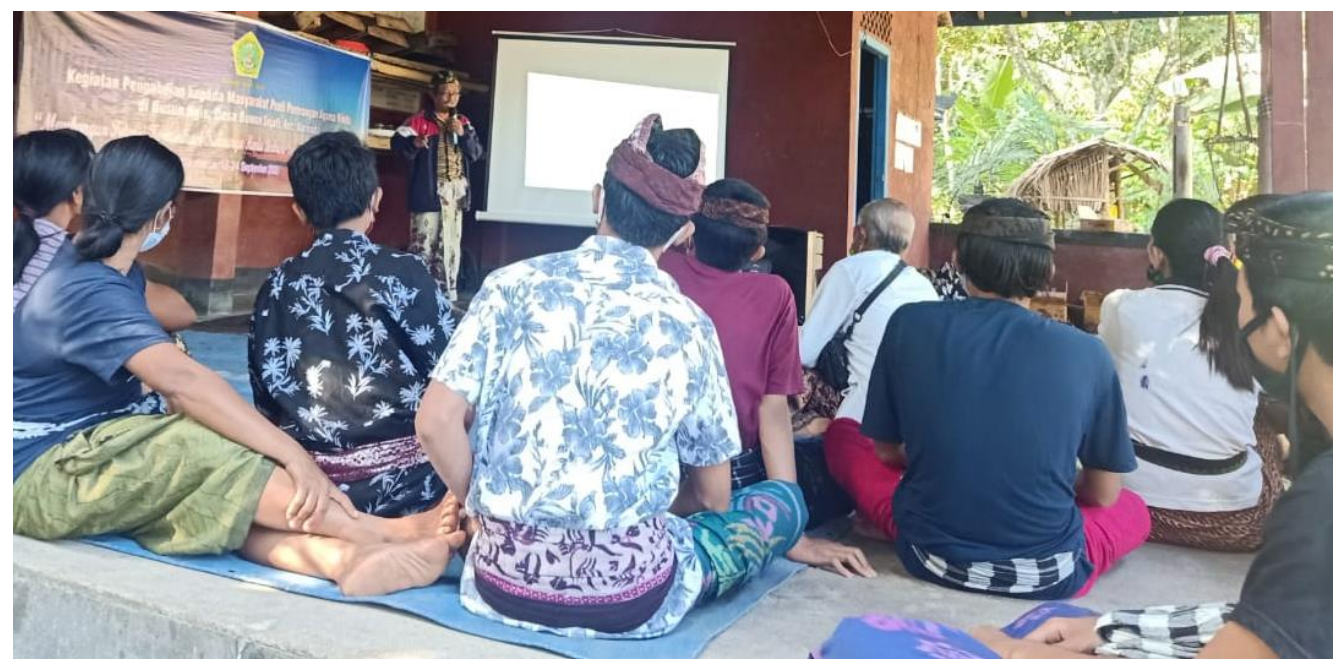

Picture 03. Coaching by Dharma wacana \& Dharma tula Method

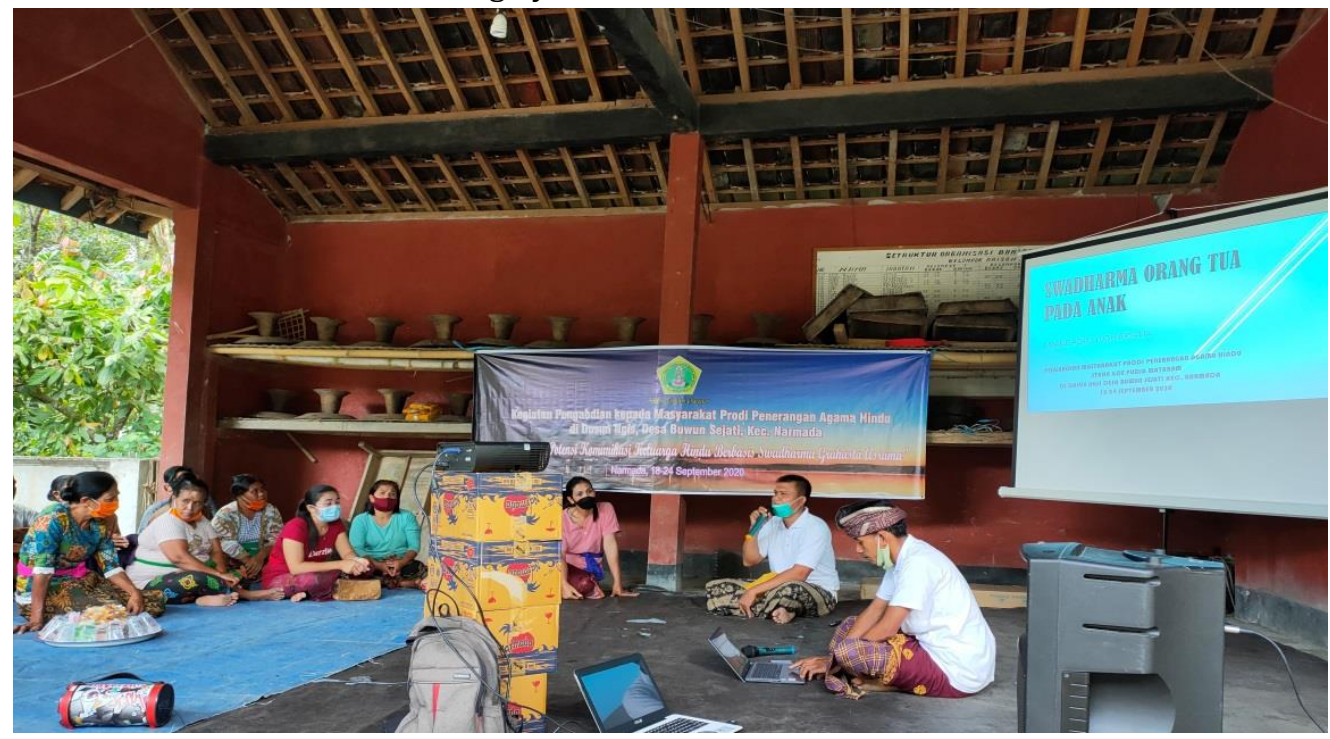

Picture 04. Coaching Family Swadharma

Based on the picture, the residents seemed enthusiastic about gathering to follow the guidance given by the service team. There was an interesting discussion during the activity. The activity took place continuously during the service implementation with different discussions but still related to tattwa and interfaith marriage laws. In the implementation of this activity, the community felt that the time given for discussion was still lacking, so it was necessary to add a longer duration of time. This activity has encouraged the intensity of communication between Hindu families who are participants in community service.

\section{c. Upakara Coaching}

The preparation stage for the development of the female adult segment in the 
process of extracting issues requires assistance in making facilities for worship ceremonies, as well as understanding the philosophical meaning of the essence of ceremonies and upakara.

The service stage by the community service team for Hindus in Ngis Hamlet understands the essence of ceremonies and ceremonies through theoretical and practical guidance on several ritual facilities, for example making woven diamonds, canang and so on. In this activity, the community can not only make upakara facilities but also be able to understand the essence or symbolic meaning of the ritual facilities. After knowing the essence of the meaning of the ceremony, people in the adult segment also nurture their children to understand the theory and practice of making ritual facilities. These activities can be seen in picture 05 below.

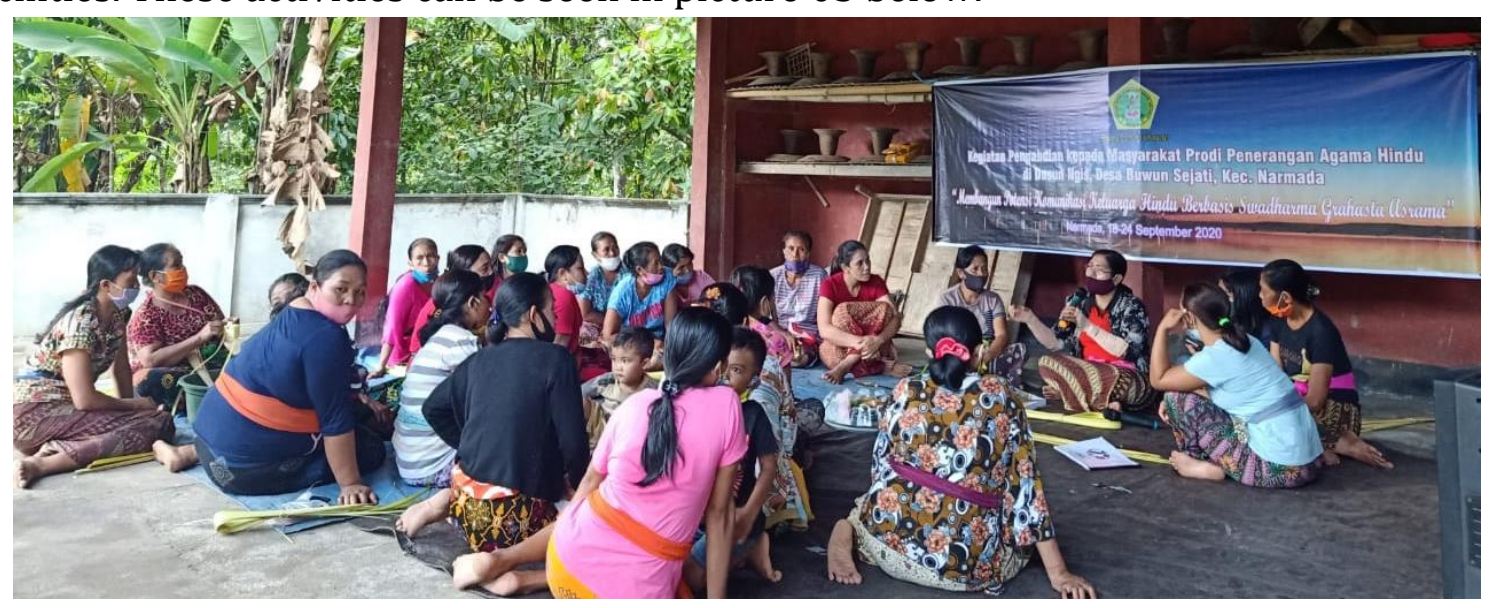

Picture 05. Coaching Ceremonial Facilities For Hindu Family

Based on the picture above, the community looks enthusiastic about participating in the training provided. Simultaneously, the women while listening to the theory about ritual facilities were also seen weaving or making upakara facilities. In this process, the community is not only able to make upakara facilities but is also able to understand the meaning of the upakara facilities that are made. Therefore, with this kind of development, the community can understand the means of ritual both theoretically and practically at the same time. With this understanding, parents who take part in the coaching can communicate their knowledge to their families regarding ceremonial facilities. This is important to do considering that not all people know the meaning of the ritual facilities they make every day. In this coaching, the importance of family communication is also instilled. The younger generation, including children, must be given understanding by their parents in order to make and understand the meaning of the ritual facilities used during religious ceremonies.

\section{d. Strengthening Religious Character In The Younger Generation}

In the preparation stage in this community service activity, the main issue obtained is that a strengthening of religious character is needed, namely strengthening sraddha and devotion especially to the younger generation, as well as to the children of Ngis Hamlet, so that various mentoring activities are carried out by the service team, 
both strengthening religious characters and media literacy.

The mentoring service stage is carried out by conducting yoga and dance training with the aim that the younger generation is more familiar with the religious culture and is proud of their culture. Hindus in Ngis Hamlet, especially the youth segment, are able to preserve arts and culture such as dance, yoga, Balinese language, and literature and are able to understand the essence of Wariga (calculation of good and bad days/times in Hinduism). By understanding the essence, the community then communicates it to the family well. Guidance on some of these things can be seen in the ability of the youth to dance and so on. These activities can be seen in pictures 06 , and 07 below.

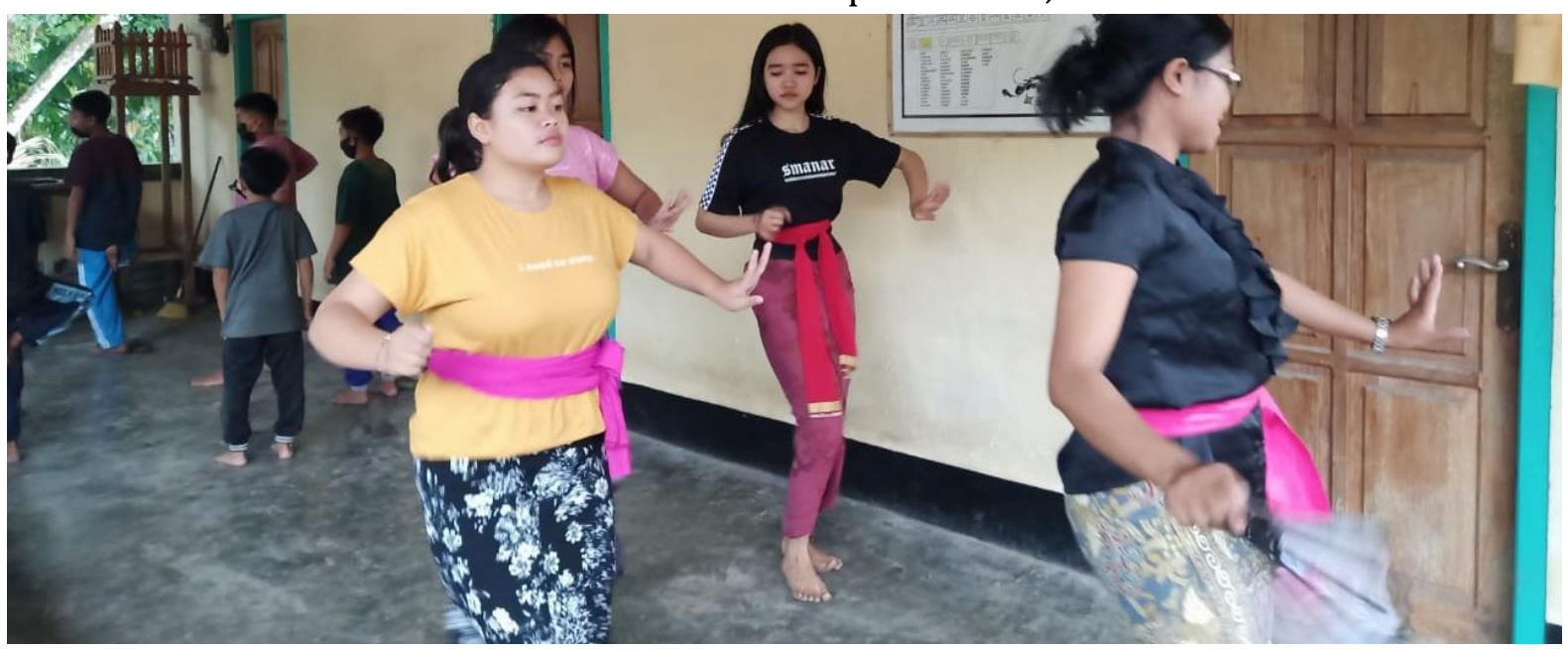

Picture 06. Teenager Practicing Dance

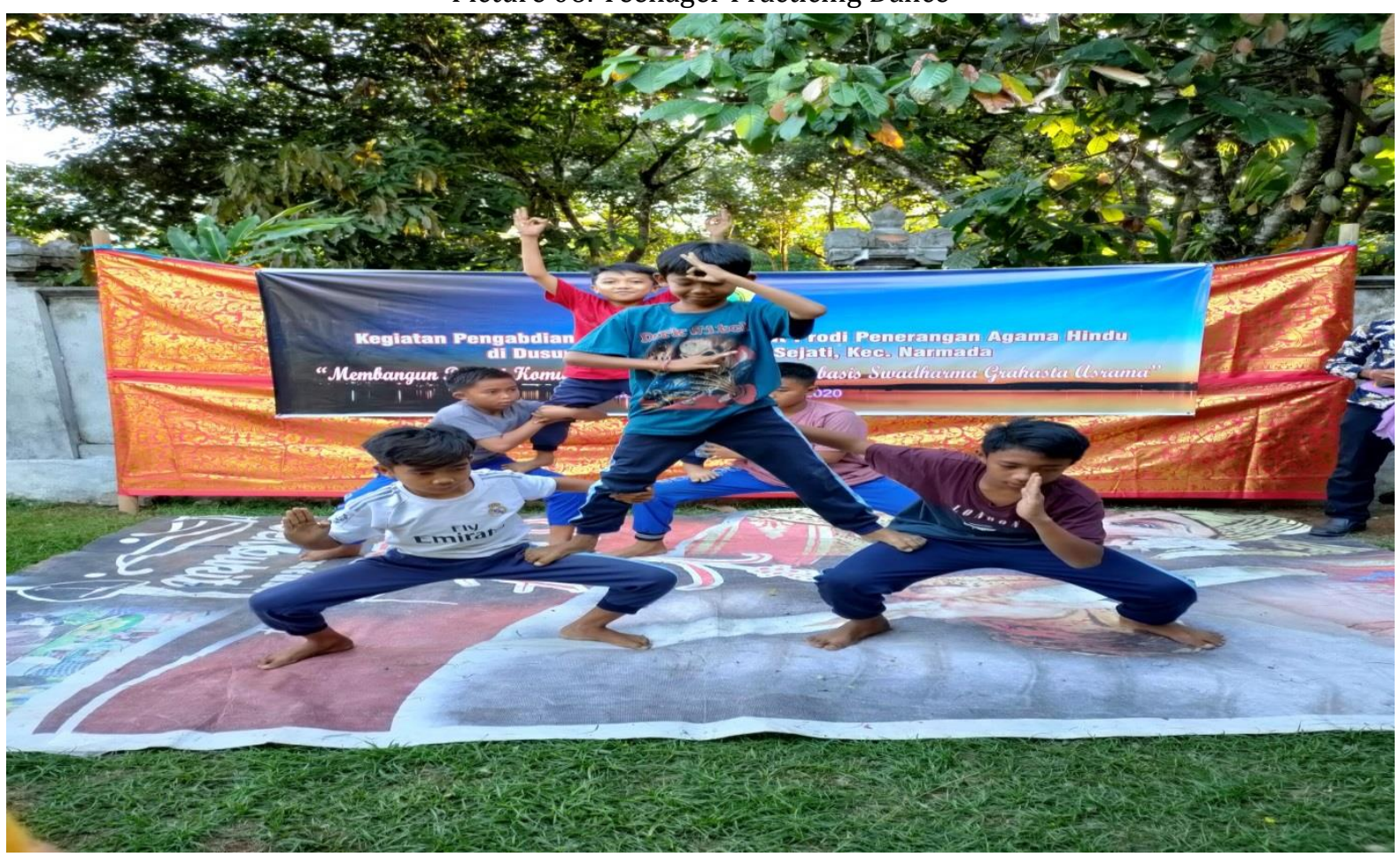

Picture 07. Kids Practicing Yoga 
Based on the picture, the teenagers and children follow the instructor's directions to dance. In addition, the children at the same time follow the yoga movements taught by other coaches. This kind of development for the community is very important. Through continuous learning and development of traditional arts, the younger generation will avoid unwanted actions. Skills like this will make teenagers more confident so that family communication will improve. After coaching, the youth told their families about their experiences while practicing. This kind of communication can prevent teenagers from various deviations.

Character strengthening is of course also carried out at the age of children, namely through the introduction of religious songs that are easy to remember and of course full of religious values. This of course aims to foster a sense of pride in their identity as Hindus from an early age. The formation of religious songs can be seen in the following picture 08:

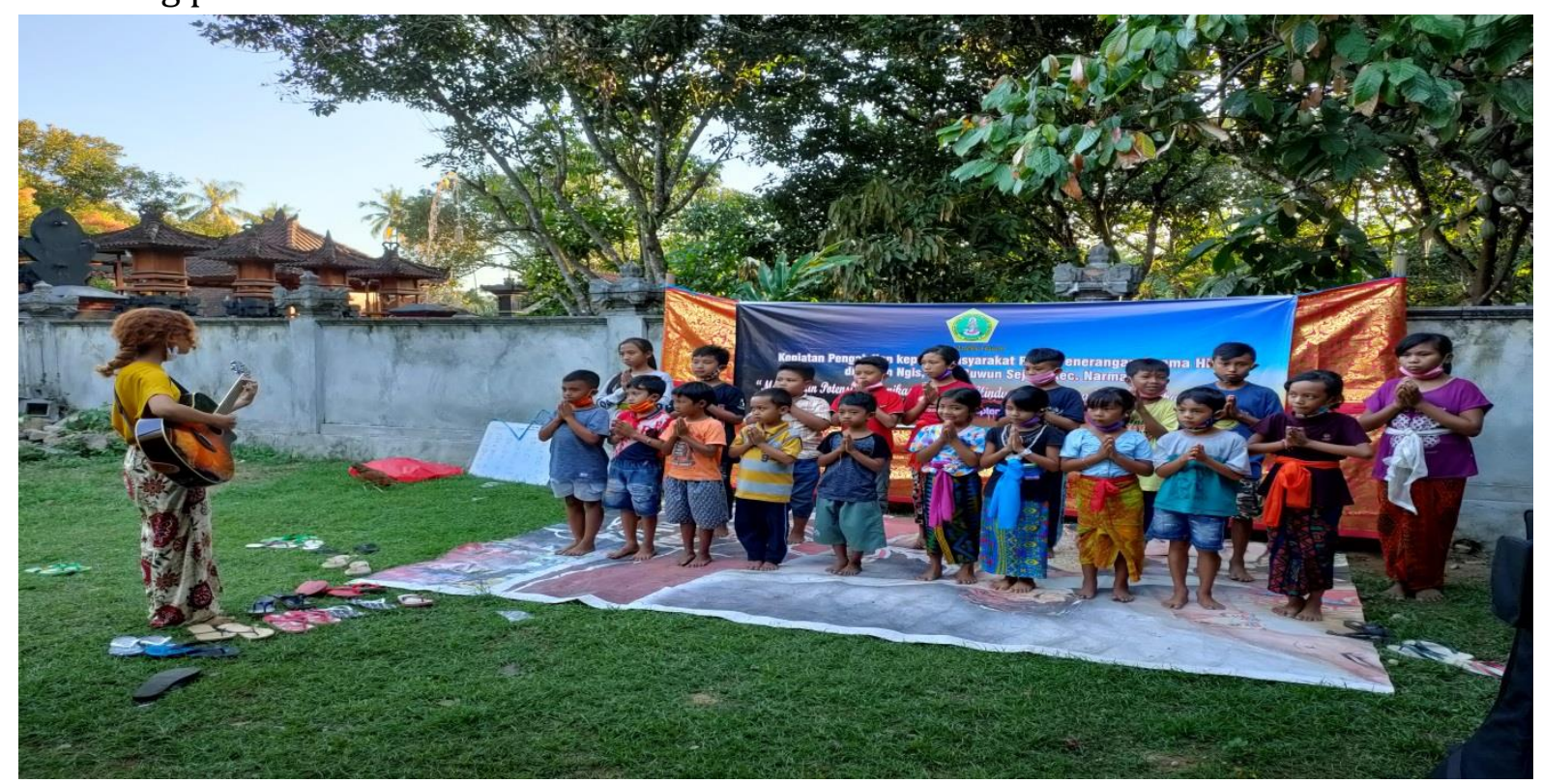

Picture 08. Coaching Of Relgious Song

In the youth segment, assistance is also provided to teenagers in terms of dharma discourse or lecture techniques. The dharma discourse technique needs to be given from a young age so that the younger generation of Hindus has the confidence to appear in a wide audience as a dharma discourse or lecturer. In assisting the dharma discourse technique, an understanding of religious teachings is given so that the lectures given have religious values in them. The development of this technique can be seen through dharma tula or discussions with teenagers in the following picture 09: 


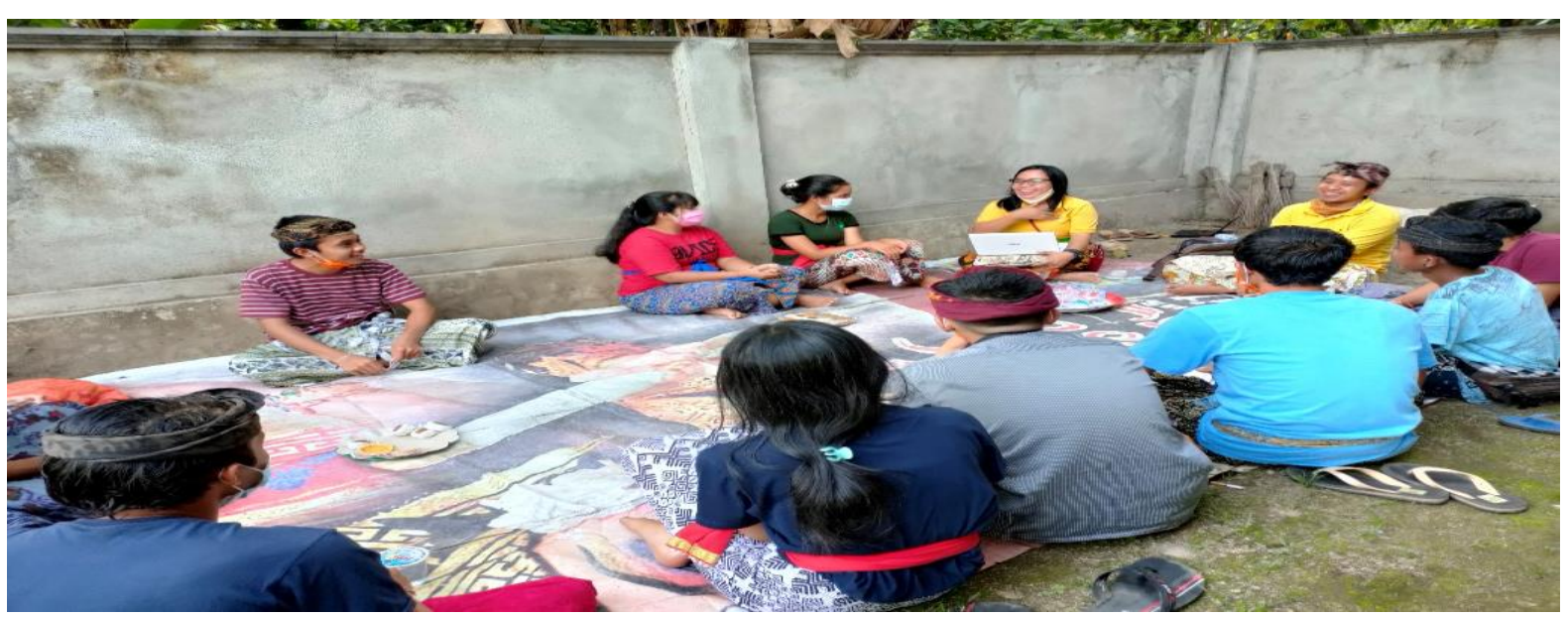

Picture 09. Discussion Of Dharma Wacana Techniques

In addition to material on strengthening the religious character of the young generation of Hindus in Ngis hamlet, assistance was also provided on understanding journalism literacy. This assistance is needed so that this young generation understands the news that develops in the mass media and social media so that they are not easily provoked by hoaxes. Hindus are able to implement journalism techniques by fostering digital media literacy. This can be seen through coaching with the Dharma Tula model or discussions about media literacy which are carried out in picture 10 below.

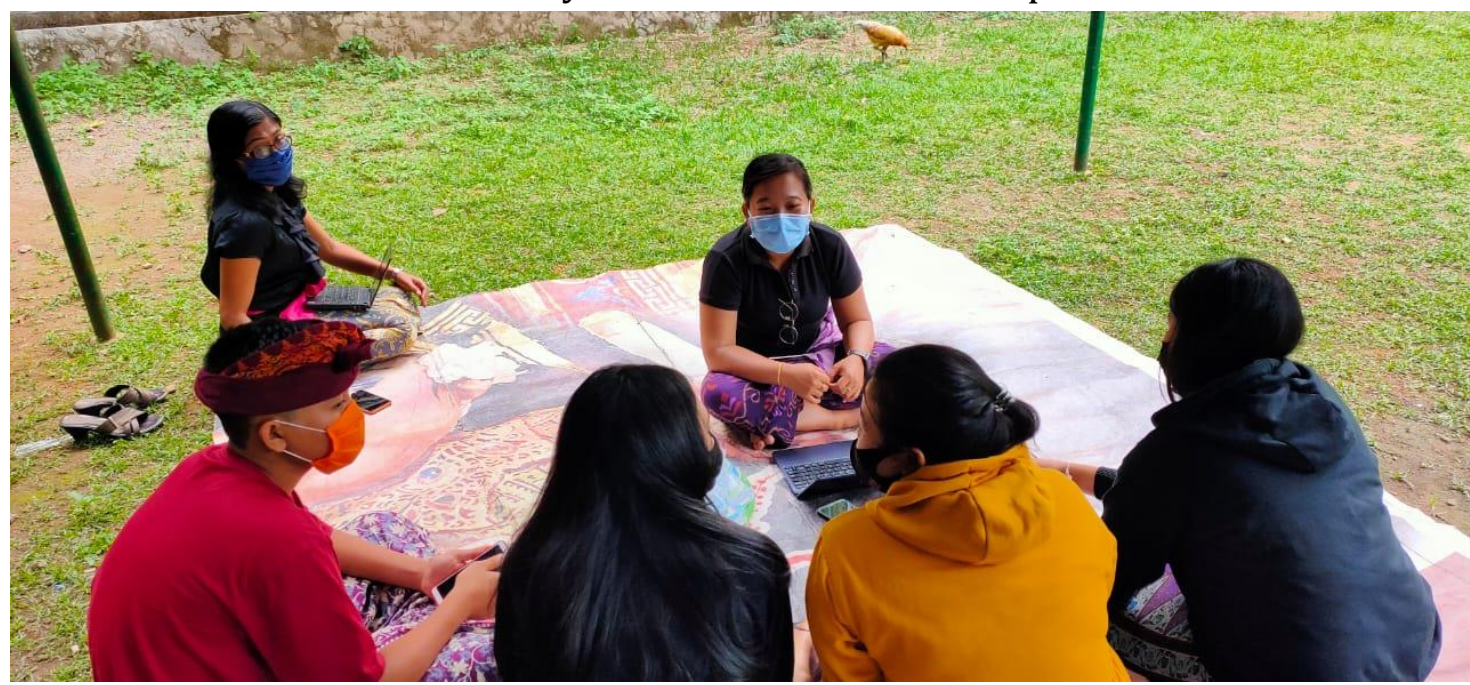

Picture 10. Journalism Technique

Based on the picture, the teenagers are equipped with an understanding of journalism techniques in the digital era. This is because digitalism has penetrated the surrounding community. The rise of fake news and the frequent occurrence of violations related to social media encourage the importance of this media literacy. In addition, almost all service participants are used to using digital media. Therefore, to avoid the negative impact of media including social media, the service coach provides an understanding to participants about media literacy. The material is packaged in an attractive manner. The participants were equipped with techniques for packaging messages on social media and also given an understanding of how to recognize fake 
news with journalism techniques. The coach also said that digital media must be used effectively so as not to reduce the intensity of family communication.

\section{e. Formation of Pasraman as a Non-Formal Educational Institution in Ngis Hamlet, Buwun Sejati Village, Narmada District, West Lombok Regency}

The preparation stage based on the issues obtained, which leads to strengthening sraddha and devotion to the younger generation of Hindus in Ngis Hamlet, is deemed necessary to establish a pasraman as a non-formal educational institution as a continuation of community service that has been carried out. Pasraman is a Hindu religious educational institution. Pasraman is a place for people to gain religious knowledge. The initiation of the establishment of the pasraman was delivered by the service team as shown in picture 11.

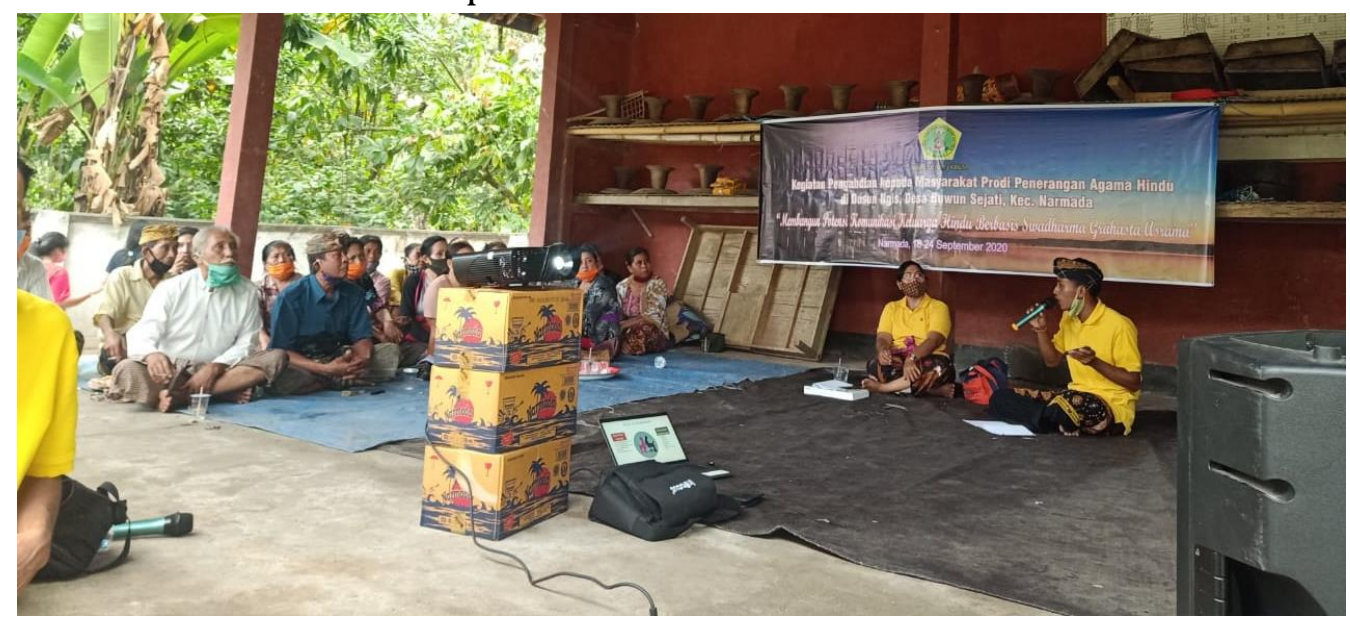

Picture 11. Pasraman Establishment

Based on the picture, the residents seemed enthusiastic about listening to the presentation of the material from the service team. Materials regarding the opportunities and challenges of establishing a pasraman were delivered through the dharma discourse and dharma tula methods. After the presentation of the material followed by a discussion. At the end of the discussion, the community agreed to the establishment of the Widya Gitanjali Pasraman at the service location. The establishment of the non-formal pasraman strongly supports the occurrence of intense family communication. The running of the pasraman is supported by parents so that their children are enthusiastic about learning at the pasraman.

The service stage carried out by the community service team for Hindus in Ngis Hamlet was able to establish a non-formal pasraman named Pasraman Widya Gitanjali. This Pasraman was founded on the initiation and invitation of the dedicated team. The hostel is managed by residents of Ngis Hamlet with the composition of the Pasraman Chair, I Nengah Wediastawa. Then I Gede Wedana as secretary, and I Wayan Sumerti as treasurer. The subjects taught are Hindu Religious Education, Yoga, Balinese Script and Language, Dance, Dharma Gita, Upakara. With the establishment of the pasraman, it is hoped that it can become a forum for the younger generation of Hindu Ngis to gain religious knowledge so that religious beliefs become stronger. The establishment of the 
Widya Gitanjali Pasraman can be seen in the following picture 12:

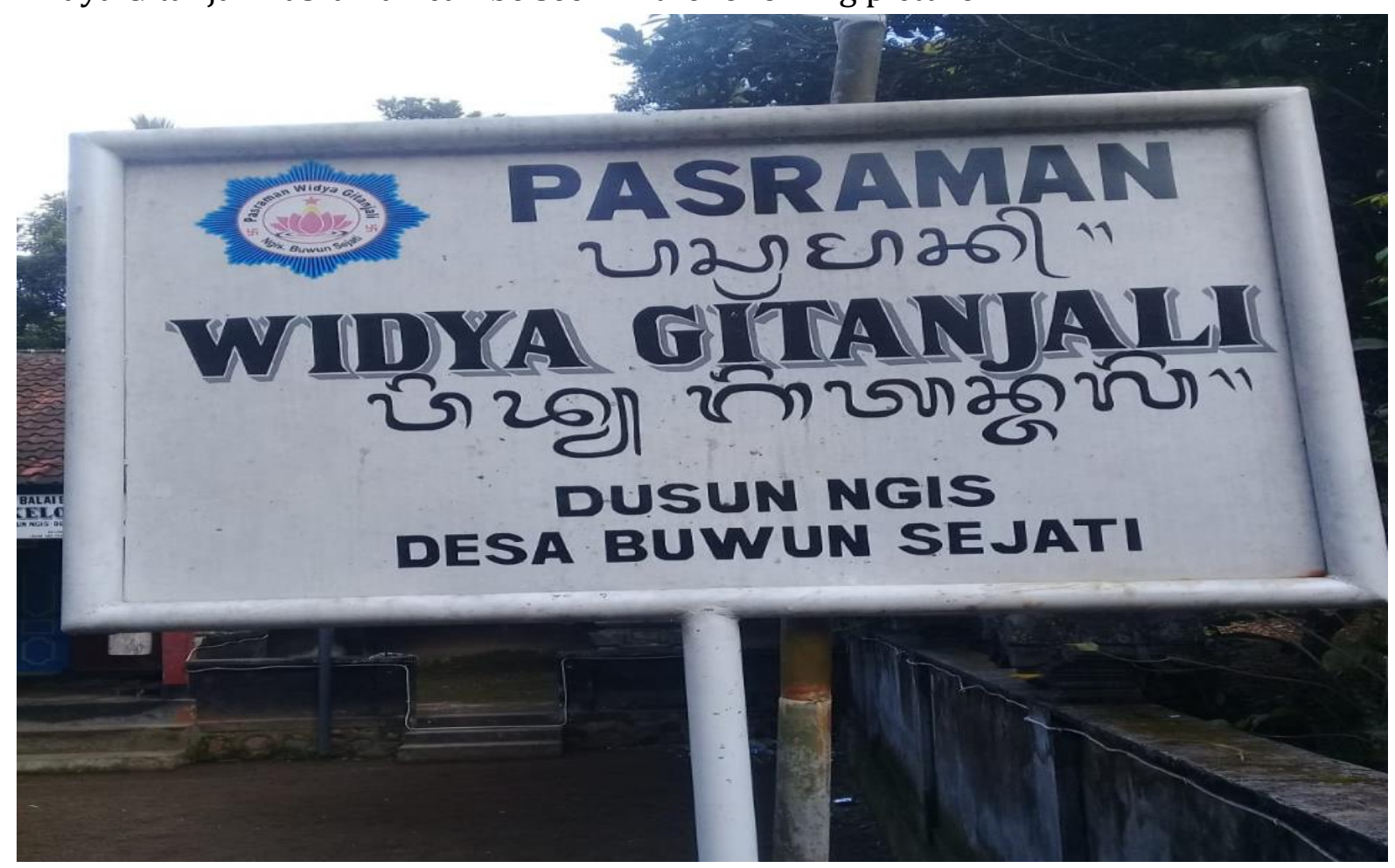

Picture 12: Widya Gitanjali Pasraman

The final stage of this mentoring is reflection. Reflection is done by re-explaining by the coaching participants about what they got during the coaching process, they explain the material they get based on their understanding. In addition, reflection is also carried out by parents by forming pasraman as a non-formal educational institution. The establishment of the Widya Gitanjali Pasraman is evidence of the efforts of Hindus in Ngis Hamlet, Buwun Sejati Village to continue to strengthen religious character by continuing to deepen their religious knowledge, especially the younger generation.

\section{Discussion}

Building family communication through swadaharma grahasta dormitories is a problem faced by many Hindu families in the current era of the industrial revolution 4.0. The millennial generation (Gen Y) who was born in the 1980s to the 1990s and the early 2000s has a very different mindset from their parents who are the older generation of Baby Boomers (Gen X). The character of this millennial generation is quick to respond to changes that occur due to the influence of internet-connected digital technology 11. Social media such as Facebook, Twitter, Instagram, WhatsApp Messenger, YouTube, and so on greatly affect the mentality and attitude of this generation. They prefer to spend their time working with gadgets. The gadget that they always carry everywhere is a smartphone. They believe that their smartphone can change the world and everything in it.

11 Edy Chandra, "Youtube, Citra Media Informasi Interaktif Atau Media Penyampaian Aspirasi Pribadi," Jurnal Muara Ilmu Sosial, Humaniora, Dan Seni 1, no. 2 (2017): 406-417. 
Grahasta dormitory is a level in the teachings of Hinduism where a person has lived a family life. But problems arise if those who take this level choose to marry a partner of a different religion. Family communication as a form of swadharma grahasta hostel is expected to be able to change the mindset of this millennial generation. The contamination of gadgets in the digital world that they experience in each of their social media accounts takes time to recover. The existence of publications on social media about certain religious teachings that are better than the teachings of other religions is a common thing. This kind of mindset must be straightened out through family communication, the implementation of which is in the form of advice to early childhood children about Hindu religion lessons so that later they will set their hearts on Hinduism. The fortress that is able to protect the younger generation of Hindus is Sradha. If the teachings of Panca Sradha have been applied correctly, this will fortify the millennial generation, namely the younger generation, from being influenced by the teachings of other religions.

How do you as a Hindu be forever able to set your heart to be a Hindu? The answer to this problem is to implement the teachings of panca sradha which adapts to the industrial revolution 4.0 where we as Hindus must take advantage of existing social media to publish these teachings of panca sradha to the younger generation because anything published on social media accounts will be able to change their perspective. and the existing world will be ready to change at any time via a smartphone. The teachings of Panca Sradha are probably too general to be the answer whenever this problem arises.

Is there any other alternative to solve this problem? The answer is there. Because so far, many Hindu families have started to rarely teach Hindu culture as well as religious art traditions that will be able to glue the younger generation together to continue to embrace Hinduism. This Hindu religious art tradition is in the form of mekidung teachings (Hindu religious sacred songs), sewing, dances for yadnya ceremonies, and reading the verse of the Ramayana and Bhagavad Gita. It is certain that with all of these efforts, our millennial generation will continue to understand the teachings of Hinduism and be able to set their hearts on Hinduism for the rest of their lives.

Communication is very crucial in connecting everything ${ }^{12}$. Communication that connects messages from communicators and communicants so that the goals of what is expected can be achieved. The purpose of communication during the discussion on community baths in the hamlet of Ngis, Buwun Sehati Village, Narmada District is to achieve effective communication in the grahastha hostel. The communication that occurs in the discussion occurs in interpersonal communication, mass communication, and interpersonal communication. 2017).

12 Onong Uchjana Effendy, Ilmu Komunikasi: Teori Dan Praktek (Bandung: PT Remaja Rosdakarya, 
The following is an explanation of the discussions that took place in community service starting with questions from the community as participants in the service and receiving responses from resource persons. The discussion is described using appropriate communication theories, so as to be able to answer all the existing problems.

Behaviorism communication theory, this communication theory was developed by a scientist from the United States named John B. Watson. This Behaviorism theory includes all behavior, including retaliation or response to a stimulus or stimulus ${ }^{13}$. This means that there is always a link between the stimulus and the response to human behavior. If a stimulus or stimuli is received by someone. This theory can provide an alternative to answer problems regarding the influence of provocation activities from outside religious teachings and be able to fortify themselves for Hindus to be able to survive and overcome them.

How as Hindus fortify themselves so as not to be influenced by outside religious teachings? The answer is to learn to control the Sadripu (six enemies in humans) on yourself. The nature of triguna (satwam, rajas, and tamas) especially rajas and tamas need to be removed because it will harm oneself, while the nature of animals needs to be implemented because of the value of virtue will emerge through it. In general, people who are easily influenced by external religious teachings are because the person concerned is to bound by the nature of rajas and tamas so that it is easy to be swayed to be persuaded and seduced to change religions and besides that, the teachings of Panca Sradha which he has are very rarely practiced in his daily life

Behaviorism communication theory is used to strengthen questions and answers because there is a stimulus in all behavior, including actions. Response actions regarding how to fortify oneself from outside influences and the desire to convert. With the answer given through mass communication by the speaker, the stimulus that emerges from the communication is so that actions and responses from the community appear to live life in accordance with the Panca Srada.

The informative theory was developed by Shannon and Weaver ${ }^{14}$. Information theory is one of the classical theories, where this theory focuses on communication as a message transmission and how the transmitter uses the media in communicating. In this case, if the media signal used is good, then the communication will be effective, and vice versa. If the media signal is not good, then communication will not run smoothly. The assumptions of this theory are very suitable for the lives of teenagers or millennials. This means that the more often we provide understanding to Hindu youth about the reviews of Hindu religious scriptures such as the Bhagavad Gita, they will be aware of the teachings of Panca Sradha.

13 Supratman, Lucy Pujasari, and Adi Bayu Mahadian, Psikologi Komunikasi (Yogyakarta: Deepublish, 2016).

${ }^{14}$ Ambar, "Teori Informatif Konsep Penjelasan Lengkap." 
As a Hindu teenager, what should you do to be able to defend yourself from the influence of other people? the answer is to understand the teachings contained in the Bhagavad Gita. Bhagavad Gita as the fifth Veda or Pancama Veda is free to be read and owned by all people of color (obligation) in the strata of Hindu society. We recommend that social media such as Facebook can be used to publish the teachings of the Panca Sradha contained in the Bhagavad Gita. Don't be quick to believe issues of comparative religion that are deliberately created by parties outside of Hindus with the aim of provoking Hindus to divide and eventually want to be invited to convert. Through smartphones that have many social media accounts, millennials, namely the younger generation, should have easier access to information about the teachings of the Vedic scriptures. If the teachings of the five sraddha and Vedas are well understood by the younger generation, no matter how hard the adherents of other religions provoke the Hindus, the Hindus will still survive and the srad alone will not be shaken. Yes, the key is to use information and communication media to maintain the teachings of Hinduism.

The informative theory is used to dissect the questions in the discussion above. In communication-based on informative theory, the answer given in the discussion is that there is communication that uses message transmission, where the message conveyed can run effectively so that the results are obtained where teenagers carry out Hindu religious teachings well.

Constructive Theory, this theory developed by Piaget and Vygotsky is two names that are always associated with this theory 15. Constructivism theory assumes that humans always have their own view of reality, they are always looking for and studying to find a first and second language. On the other hand, this theory is also defined as generative learning. Learning is an action to create meaning from what has been learned.

How do you as parents guide children who have not received religious lessons at school, such as giving advice to early childhood children about religious lessons so that they understand what Hinduism is like? The answer is by giving examples of reciting Tri Sandya pujas and five prayers in praying activities with the family at home. In addition, encouraging children to study religion at the pasraman is also very important. Teaching children to say the Hindu food greetings, namely Om Swastyastu when going and returning home to their parents and siblings is one thing that can be done as well. Provide a review of the meaning of the verses contained in Vedic scriptures such as the Bhagavad Gita about the values of Hindu religious teachings and this is given by parents as a form of affection for their children. Practicing the teachings of compassion or tat twam asi in social life in society, for example, is ahimsa karma. If parents give all these teachings to their children then their children will grow up to become intellectual Hindu youth because the first school for a child is at home with his parents as an imaging

15 Suparlan, "Teori Konstruktif Dalam Pembelajaran," Jurnal Keislaman Dan Ilmu Pendidikan 1, no. 2 (2019): 79-88. 
teacher. Although informal schools there will be no religious lessons given, these children are already able to know the teachings of Hinduism through education in their respective homes with their parents.

The constructive theory is used to dissect the question above because it is based on the constructive theory that parents have their own views on how to educate their children and parents have ways of showing action so that their children walk on the path of dharma.

\section{Conclusion}

Community Service Activities carried out by the Hindu Religion Information Study Program in 2020 in Ngis Hamlet, Buwun Sejati Village, Narmada District, West Lombok Regency, West Nusa Tenggara Province, have been able to build Hindu family communication based on swadharma grahasta dormitories. This is shown by increasing the devotion of Hindus by living a good and right religious life. The establishment of the Widya Gitanjali Pasraman is evidence of the efforts of Hindus in Ngis Hamlet, Buwun Sejati Village to continue to strengthen religious character by continuing to deepen their religious knowledge, especially the younger generation. The coaching agenda through the service-learning method which consists of the preparation stage, service stage, and reflection stage has been able to provide changes to the communication pattern of Hindu families. The entire coaching activity carried out involves all levels of society capable of creating a harmonious family life based on sraddha and devotional service that is sourced from the Vedic Scriptures. In addition, the community development program by the Hindu Religious Information Study Program has been able to build good relations between the community and STAHN Gde Pudja Mataram.

\section{Acknowledgements}

As an obligation and form of academic responsibility, lecturers contribute their knowledge for the welfare of society. In line with the above activities, we extend our gratitude to Asung Kertha Wara Nugraha Ida Sang Hyang Widhi Wasa. Community Service Group activities, in Ngis Hamlet, Buwun Sejati Village, Narmada District, West Lombok Regency, NTB Province in 2020 can be completed on time. We take this opportunity to express our sincere thanks to:

1. Plt. STAHN Chancellor Gde Pudja Mataram for all the assistance and facilities provided to us in Community Service group activities in Ngis Hamlet, Buwun Sejati Village, Narmada District, West Lombok Regency, NTB Province.

2. Deputy Chairs I, II, and III, as the person in charge and coach in community service activities for the Information Study Program of the Dharma Duta Department.

3. P3M which has provided ideas for carrying out Community Service group activities as a form of implementing the Tridharma of higher education. 
4. Head of the Dharma Duta Department who has contributed ideas ranging from implementing community service group activities to making reports.

5. Mr. Head of Buwun Sejati Village, Head of Ngis Hamlet, Head of Banjar Kelodan na Kertayasa, Head of PHDI Narmada District, who have received and provided a place from the beginning to the end of the activity, always helping to carry out the activities of the Community Service group.

6. All members / Community Service Trustees of the Hindu Religious Information Study Program, Department of Dharma Duta.

7. All parties who have assisted in carrying out community service, both moral and material assistance, so that the implementation of this Community Service group activity can be completed properly.

\section{Reference}

Ambar. "Teori Informatif Konsep Penjelasan Lengkap."

BPS Kabupaten Lombok Barat. Kecamatan Narmada Dalam Angka. Kabupaten Lombok Barat: Badan Pusat Statistik, 2020.

Budiwanti, Erni. "Adat, Islam, and Dakwah Movement in Bayan, North Lombok." Heritage of Nusantara: International Journal of Religious Literature and Heritage (2016).

-_- Islam Sasak; Wetu Telu Versus Waktu Lima. LKIS PELANGI AKSARA, 2000.

Chandra, Edy. "Youtube, Citra Media Informasi Interaktif Atau Media Penyampaian Aspirasi Pribadi." Jurnal Muara Ilmu Sosial, Humaniora, Dan Seni 1, no. 2 (2017): 406-417.

Effendy, Onong Uchjana. Ilmu Komunikasi: Teori Dan Praktek. Bandung: PT Remaja Rosdakarya, 2017.

Google Maps. "Desa Buwun Sejati.”

Indonesia, Presiden Republik. "Undang-Undang Republik Indonesia Nomor 20 Tahun 2003 Tentang Sistem Pendidikan Nasional." Jakarta: Pemerintah Republik Indonesia (2003).

Kementerian Agama NTB. "Suparlan: “ PR FKUB, Masalah Nikah Beda Agama Dan Rumah Ibadah."

Presiden Republik Indonesia. Undang-Undang Republik Indonesia Nomor 12 Tahun 2012 Tentang Pendidikan Tinggi, 2012.

Setyowati, Endah, and Alviani Permata. "Service Learning: Mengintegrasikan Tujuan Akademik Dan Pendidikan Karakter Peserta Didik Melalui Pengabdian Kepada Masyarakat." Bakti Budaya 1, no. 2 (2018): 143.

Suparlan. "Teori Konstruktif Dalam Pembelajaran." Jurnal Keislaman Dan Ilmu Pendidikan 1, no. 2 (2019): 79-88.

Supratman, Lucy Pujasari, and Adi Bayu Mahadian. Psikologi Komunikasi. Yogyakarta: Deepublish, 2016.

"Mediasi Kawin Selarian Beda Agama." Diskominfo Dan Statistik Kabubaten Lombok Barat. 
Peraturan Menteri Agama Republik Indonesia Nomor 19 Tahun 2016 Tentang Statuta Sekolah Tinggi Agama Hindu Negeri Gde Pudja Mataram, 2016. 